\title{
Residents' Evaluation of Apartment Community Spaces with Longitudinal Approach
}

\author{
Tae Kyung Lee, Hye Gyoung Kang, and Jeong Tai Kim
}

\begin{abstract}
The purpose of this study is to investigate the evolution in the use and demands for community spaces of apartment complexes based on empirical resident assessment. To this end, four apartment complexes in Busan of South Korea were selected and their residents were each surveyed twice over 10 years. The first survey was conducted in 2001 and the second in 2011. The survey results were then compared to analyze use, satisfaction and demands with respect to community spaces. The analysis included frequency analysis and variance analysis aided by SPSS WIN 18. The results are followings. Firstly, some community spaces of apartments changed in their usage function. And problems arose in management and safety aspects, such as deterioration, breakdown and noise. Secondly, the use of community space in 2011was reported significantly lower than 2001. Lastly, residents desired greater access to exercise facilities and to green spaces to better enrich their lives. This study will serve as a basis for future design of sustainable community spaces in apartment complexes.
\end{abstract}

Index Terms-Change of use and need, community space, residents' evaluation, sustainable communities of apartment complex.

\section{INTRODUCTION}

Apartments were first introduced to Korea in the early 1960 s to solve the housing shortage in urban areas. Since then, they have become the most common form of urban housing. An apartment complex is a form of residence that includes both private and public areas, simultaneously guaranteeing residents the privacy of their individual housing units and the comforts of their community lives.

A community space is defined as one which supports the public lives of the residents. These are areas where residents can build bonds with neighbors, develop their sense of belonging, and enjoy different activities and social interactions. In modern times, many people lack the opportunity for such activities. Thus community spaces are important in helping the resident community to unify and to improve its quality of life.

To date, Korea has focused on developing high-rise high-density apartments to maximize on economy of scale. These apartments have tended to overemphasize the

Manuscript received June 14, 2014; revised July 30, 2014.

This work was supported by the National Research Foundation of Korea(NRF) grant funded by the Korea government(MSIP)(No. 2008-0061908)

Tae Kyung Lee is with the Pusan National University of Busan, 609-735, South Korea. She is now with the Department of Housing and Interior Design, Elderly Research Institute (e-mail: sunney@ pusan.ac.kr).

Hye Gyoung Kang is with Kyung Sung University of Busan, 608-736, South Korea (e-mail:segerow@ks.ac.kr).

Jeong Tai Kim is with the Architectural Engineering Department, Kyung Hee University, Yongin 446-701, South Korea (e-mail: jtkim@khu.ac.kr). development of housing units at the expense of barely meeting the minimum legal requirements for community spaces. As a result, many apartment complexes are poorly equipped with shared and outdoor spaces, and so struggle to meet residents' demands for leisure or social activities within the complex. This has become a hotly debated topic in the realm of housing development.

As quality of life has improved and public demands for a healthy living environment have grown, more people have become interested in the concept of a sustainable community, one which provides greater access to community spaces and greater development of community bonds.

Sustainable development has become a universal initiative in housing development after the publishing of The Brundtland Report: Our Common Future in 1987, and after the proclamation of the Habitat Agenda in 1996. Sustainable development is usually discussed in environmental, social and economic dimensions, which the topic of community space often being raised during discussions on social sustainability. Socially sustainable housing development is understood to be housing which includes public spaces where residents can develop bonds within the community to improve their social lives and overall quality of life. Community design creates sustainable living places which meet the basic needs of the residents and further enrich their lives.

Therefore, in order to maintain sustainable community designs of apartment complexes, it is critical to secure community spaces that meet the demands of residential life.

Previous studies have found that community spaces play a critical role in the improvement of residential housing satisfaction [1]-[3]. Providing public facilities and spaces within a community helps residents build bonds with their neighbors and affection for the neighborhood [4]-[6]. A wide range of efforts has been made on this front, including a study to investigate resident demands for community spaces [7]-[9], a concept study for sustainable community design [10]-[14], and a study exploring the creation of community spaces as a form of sustainable community design [15]-[18].

As such, previous studies have largely focused on the use of and demands for community spaces, and on the guidelines or frameworks for the design of community spaces. However, these studies have failed to address changes in the use of community spaces from a sustainable design perspective.

Thus, this study is designed to look at the evolution in the use and purpose of established community spaces in apartment complexes.

This study will serve as a basis for future design of sustainable community spaces in apartment complexes, particularly in the renovation of old and deteriorating complexes. 


\section{The Purpose And Methodology of Study}

\section{A. Purpose of Study}

The purpose of this study is to investigate the use of and demands for community spaces of apartment complexes based on empirical resident assessment. To this end, four apartment complexes were selected and their residents were each surveyed twice over 10 years. The first survey was conducted in 2001 and the second in 2011. The survey results were then compared to analyze use, changes in use, satisfaction and demands with respect to community spaces.
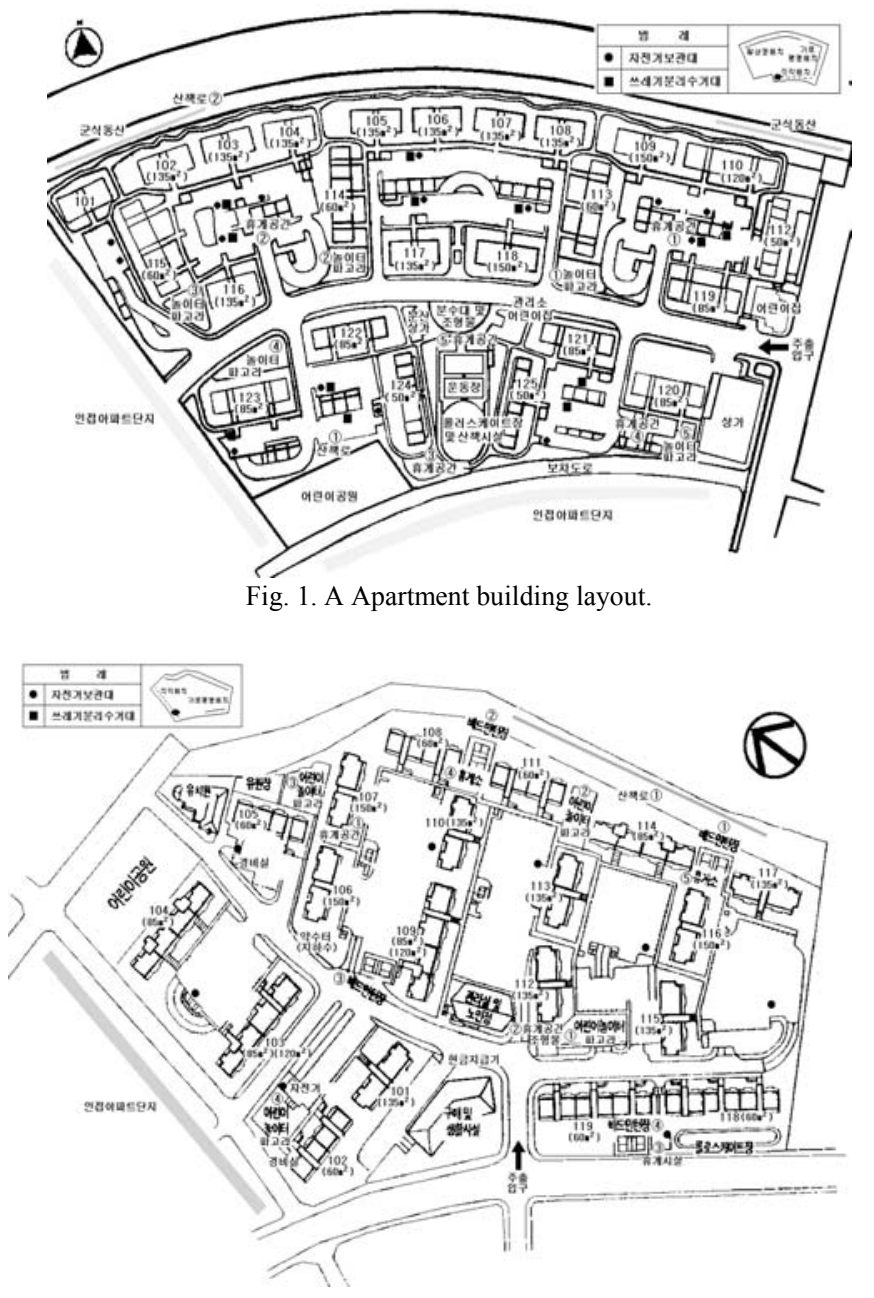

Fig. 2. B Apartment building layout.

\section{B. Research Method}

The 4 research subjects were apartment complexes located in Haeundae New Town, Busan of South korea. Factors considered for the selection included the total number of households, and the types and forms of community spaces provided in the complexes. Further field research and surveys followed. The former was conducted to understand how the community spaces were being used. The survey questionnaire included questions on resident demographics, satisfaction with and use of community spaces, and demands/desires for further community spaces (including demands for new facilities). Satisfaction, use and demands were measured on a 5-point scale: 5: very satisfied/very frequently used/highly needed, 4: satisfied/frequently used/needed, 3: moderately satisfied/moderately used/moderately needed, 2: dissatisfied/rarely used/hardly needed, and 1: very dissatisfied/not used at all/not needed at all.

The survey was answered by residents of the 4 subject complexes, and was conducted once in 2001 and once again in 2011 ( 10 years apart). The first survey was conducted in August 2001, from which 521 questionnaires were used for analysis. The second survey was conducted in May 2011, from which 447 questionnaires were used for analysis.

The analysis included frequency analysis, crossover analysis, and variance analysis, aided by SPSS WIN 18.

\section{OVERVIEW AND CHARACTERISTICS OF SUBJECTS}

\section{A. Characteristics of Subject Apartments}

The subjects consisted of 4 apartment complexes located in Haeundae New Town, Busan of South Korea. Each complex began to accept residents after May 1996 and, at the time of research, accommodated 500 to 2,000 households. These complexes provided welfare facilities no smaller than the legally-required scale (see Table I, Fig.1- Fig.12).

The profile of the subject complexes is as follows: they began to accommodate residents sometime between March 1996 to October 1998, their building-to-land ratios are approximately $17.0 \%$, their floor area ratios are between $250.0 \%$ and $260.0 \%$, and they consist of high-rise high-density buildings of 20 stories or higher. The building arrangement patterns differ by complex, but are mostly in the crossply and/or courtyard arrangement as guided by urban planning policy.

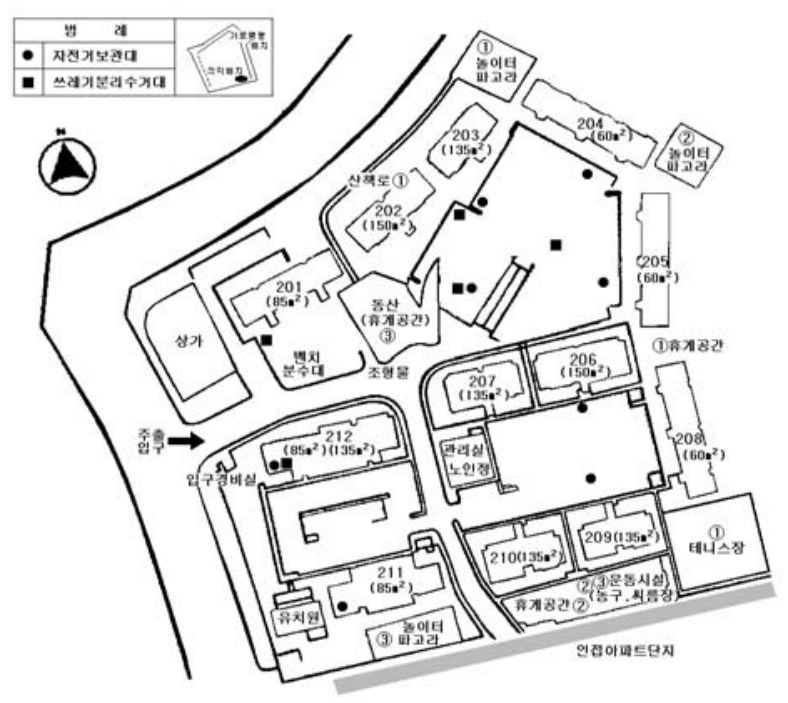

Fig. 3. C Apartment building layout.

TABLE I: THE CHARACTERISTICS OF RESPONDENTS

\begin{tabular}{|c|c|c|c|c|}
\hline Items & $\begin{array}{c}\text { Apartment } \\
\text { A }\end{array}$ & $\begin{array}{c}\text { Apartment } \\
\text { B }\end{array}$ & $\begin{array}{c}\text { Apartment } \\
\mathrm{C}\end{array}$ & $\begin{array}{l}\text { Apartment } \\
\text { D }\end{array}$ \\
\hline Occupation & $\begin{array}{l}\text { October, } \\
1996 .\end{array}$ & $\begin{array}{l}\text { October, } \\
1996 .\end{array}$ & $\begin{array}{l}\text { March, } \\
1996 .\end{array}$ & $\begin{array}{l}\text { October, } \\
1998 .\end{array}$ \\
\hline Number of & 24 & 19 & 12 & 12 \\
\hline \multirow[t]{4}{*}{ Households } & Buildings & Buildings & Buildings & Buildings \\
\hline & 24 Storeys & 24 Storeys & 23 Storeys & 27 Storeys \\
\hline & 1852 & 1358 & 956 & 1002 \\
\hline & Households & Households & Households & Households \\
\hline
\end{tabular}




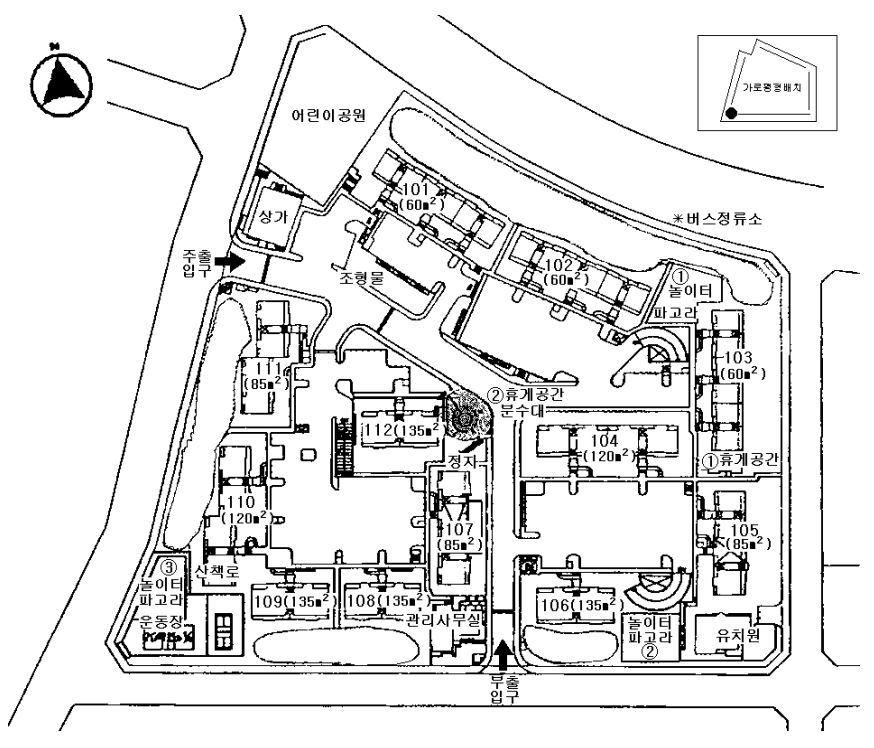

Fig. 4. D Apartment building layout.
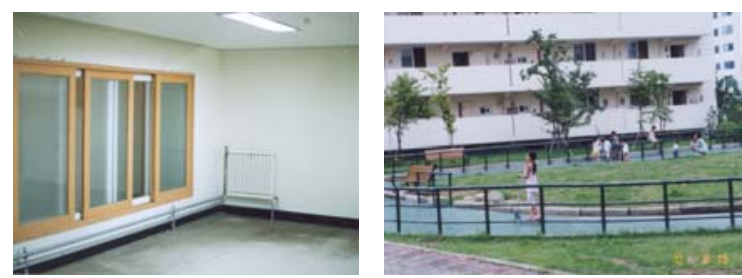

Fig. 5. A Apartment in 2001(left: multipurpose room, right: outdoor exercise space)

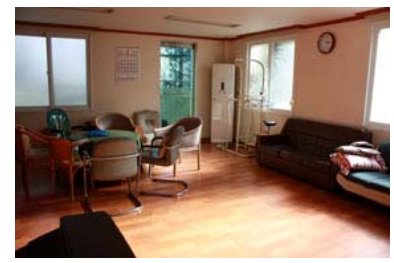

Fig. 6. A Apartment in 2011(left: multipurpose room, right: outdoor exercise space).
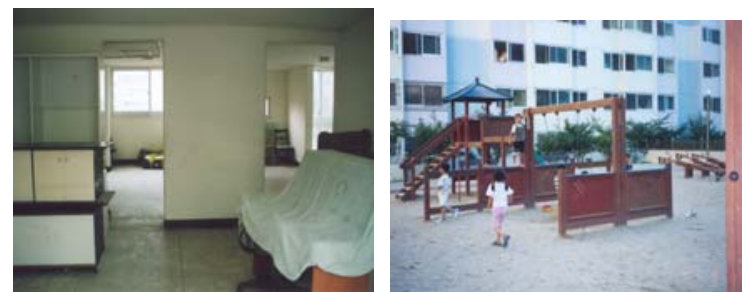

Fig. 7. B Apartment in 2001(left: multipurpose room, right: playground).

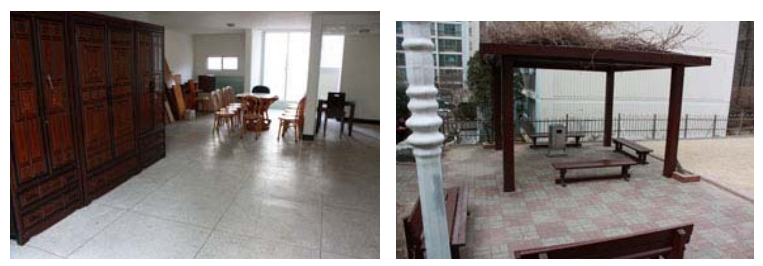

Fig. 8. B Apartment in 2011(left: multipurpose room, right: rest space).
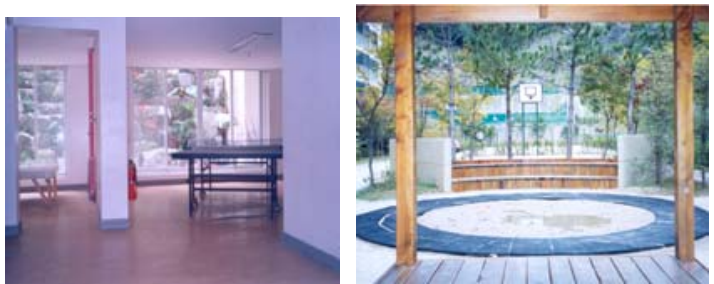

Fig. 9. C Apartment in 2001(left: multipurpose room, right: rest space).
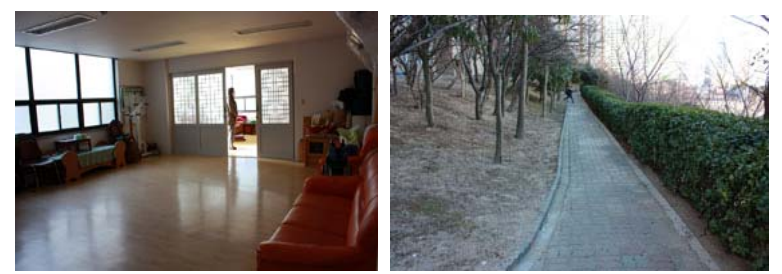

Fig. 10. C Apartment in 2011(left: multipurpose room, right: walkway).
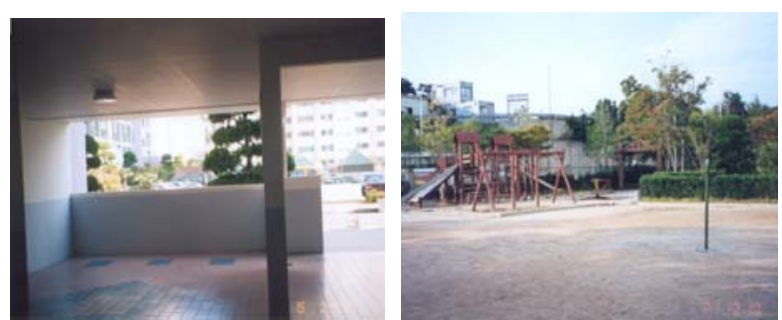

Fig. 11. D Apartment in 2001(left: multipurpose space, right: outdoor exercise space).
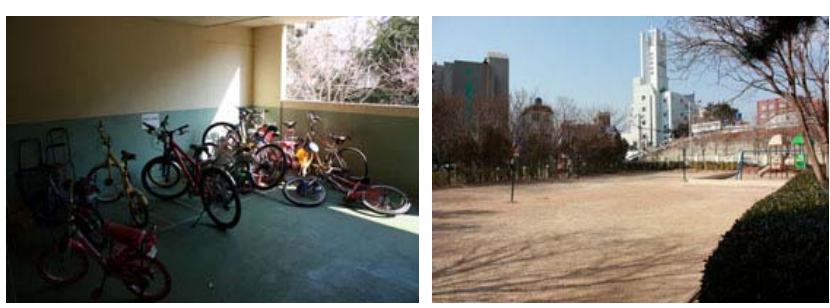

Fig. 12. D Apartment in 2011(left: multipurpose space, right: outdoor exercise space).

\section{B. Characteristics of Respondents}

To understand the general demographics of the respondents, the survey included questions on age, educational background, job, family size, family lifecycle, monthly income, house size, home ownership, and resident period(Table II).

\section{1) $1^{\text {st }}$-survey respondents}

Based on the survey data gathered, wives were 39 years old on average with $58.7 \%$ in their $30 \mathrm{~s}$ and $35.7 \%$ in their $40 \mathrm{~s}$, while husbands were 42 years old on average with $46.1 \%$ in their $40 \mathrm{~s}$ and $43.8 \%$ in their $30 \mathrm{~s}$. Both wives and husbands were found to be highly educated: $96.1 \%$ of the wives were college graduates or higher, and $87.2 \%$ of husbands were college graduates or higher.

In terms of employment, $88.5 \%$ of wives were full-time housewives. $49.0 \%$ of the husbands were office workers, $22.5 \%$ were self-employed and $14.7 \%$ were professionals.

Family lifecycle was determined based on the age of the first child: $38.0 \%$ were elementary school aged, and $30.0 \%$ were middle or high school aged. As for the family size, $61.5 \%$ of the households comprised of 4 or more members. In terms of monthly income, $42.3 \%$ fell in the bracket of 2 million to 3 million won, and $31.6 \%$ in the bracket of less than 2 million. As for the house ownership and size, $77.6 \%$ owned the houses, and $41.3 \%$ lived in $85 \mathrm{~m}^{2}-120 \mathrm{~m}^{2}$ apartments, followed by $50 \mathrm{~m}^{2}-60 \mathrm{~m}^{2}(37.0 \%)$ and $135 \mathrm{~m}^{2}$ or greater $(21.7 \%)$.

\section{2) $2^{\text {nd }}$-survey respondents}

Respondents of the second survey were found to be, on leverage, older than those of the first survey: wives were 46 years old on average with $39.4 \%$ in their 50 s or older, $33.1 \%$ 
in their $40 \mathrm{~s}$ and $27.5 \%$ in their $30 \mathrm{~s}$, while husbands were 49 years old on average with $49.9 \%$ in their 50 s or older, $31.3 \%$ in their $40 \mathrm{~s}$ and $18.8 \%$ in their $30 \mathrm{~s}$.

They were also highly educated: $73.7 \%$ of the wives were college graduates or higher and $84.8 \%$ husbands were college graduates or higher.

In terms of jobs, $71.6 \%$ wives were full-time housewives, whereas $41.8 \%$ of the husbands were office workers, $22.6 \%$ were self-employed and $22.3 \%$ were professionals.

Again, family lifecycle was determined by the age of the first child: $44.1 \%$ were adults, $18.8 \%$ were middle or high school aged, $22.3 \%$ were infants/preschool aged (including newly-wed couples with no child) and $14.8 \%$ were elementary school aged. As for the family size, $58.9 \%$ of the households had 4 or more members. In terms of monthly income, $31.7 \%$ fell in the bracket of less than 3 million won, followed by 4 million or more $47.9 \%$ and 3 million to 4 million $20.4 \%$.

As for the house ownership and size, $79.9 \%$ owned the houses, and $30.6 \%$ lived in $50 \mathrm{~m}^{2}-60 \mathrm{~m}^{2}$ apartments, $35.8 \%$ in $85 \mathrm{~m}^{2}-120 \mathrm{~m}^{2}$, and $33.6 \%$ in $135 \mathrm{~m}^{2}$ or greater.

TABLE II: THE CHARACTERISTICS OF RESPONDENTS

\begin{tabular}{|c|c|c|c|}
\hline Item & Details & $1^{\text {st }}$-Survey & $2^{\text {nd }}$-Survey \\
\hline \multirow[t]{4}{*}{ Age of wives } & 30 s or under & $306(58.7)$ & $123(27.5)$ \\
\hline & $40 \mathrm{~s}$ & $186(35.7)$ & $148(33.1)$ \\
\hline & 50 s or over & $29(5.6)$ & $176(39.4)$ \\
\hline & Total & $521(100.0)$ & $447(100.0)$ \\
\hline \multirow{3}{*}{$\begin{array}{l}\text { Education } \\
\text { level } \\
\text { of wives }\end{array}$} & College graduate or over & $255(70.6)$ & $309(73.7)$ \\
\hline & High school graduate or under & $106(29.4)$ & $110(26.3)$ \\
\hline & Total & $361(100.0)$ & $419(100.0)$ \\
\hline \multirow{3}{*}{$\begin{array}{l}\text { Occupation of } \\
\text { wives }\end{array}$} & Full-time housewife & $461(88.5)$ & $283(71.6)$ \\
\hline & Employed & $60(11.5)$ & $112(28.4)$ \\
\hline & Total & $521(100.0)$ & $395(100.0)$ \\
\hline \multirow{4}{*}{$\begin{array}{l}\text { Age of } \\
\text { husbands }\end{array}$} & 30 s or under & $227(43.8)$ & $84(18.8)$ \\
\hline & $40 \mathrm{~s}$ & $240(46.1)$ & $140(31.3)$ \\
\hline & 50 s or over & $53(10.2)$ & $223(49.9)$ \\
\hline & Total & $521(100.0)$ & $447(100.0)$ \\
\hline \multirow{3}{*}{$\begin{array}{l}\text { Education } \\
\text { level } \\
\text { of husbands }\end{array}$} & College graduate or over & $402(87.2)$ & $347(84.8)$ \\
\hline & High school graduate or under & $59(12.8)$ & $62(15.2)$ \\
\hline & Total & $461(100.0)$ & $409(100.0)$ \\
\hline \multirow{6}{*}{$\begin{array}{l}\text { Occupation of } \\
\text { husband's }\end{array}$} & Office worker & $224(49.0)$ & $161(41.8)$ \\
\hline & Self-employed & $103(22.5)$ & $87(22.6)$ \\
\hline & Production worker & $37(8.1)$ & $11(2.9)$ \\
\hline & Professional & $67(14.7)$ & $86(22.3)$ \\
\hline & Etc. & $26(5.7)$ & $40(10.4)$ \\
\hline & Total & $457(100.0)$ & $385(100.0)$ \\
\hline \multirow{5}{*}{$\begin{array}{l}\text { Size of family } \\
\text { (person) }\end{array}$} & 2 or under & $28(5.8)$ & $62(14.4)$ \\
\hline & 3 & $111(23.2)$ & $115(26.7)$ \\
\hline & 4 & 293(61.2) & 215(49.9) \\
\hline & 5 or over & $47(9.8)$ & $39(9.0)$ \\
\hline & Total & $479(100.0)$ & $431(100.0)$ \\
\hline \multirow{5}{*}{$\begin{array}{l}\text { Family life } \\
\text { cycle }\end{array}$} & Pre-School & $71(15.4)$ & $96(22.3)$ \\
\hline & Primary & $175(38.0)$ & $64(14.8)$ \\
\hline & Secondary & 138)30.0) & $81(18.8)$ \\
\hline & Adulthood & $76(16.5)$ & $190(44.1)$ \\
\hline & Total & $460(100.0)$ & $431(100.0)$ \\
\hline Average & Under 200 & $130(31.6)$ & - \\
\hline
\end{tabular}

\begin{tabular}{|c|c|c|c|}
\hline monthly & $201-300$ & $174(42.3)$ & $129(31.7)$ \\
\hline \multirow{3}{*}{$\begin{array}{l}\text { income } \\
\text { (ten thousand } \\
\text { won) }\end{array}$} & $301-400$ & $407(26.0)$ & $83(20.4)$ \\
\hline & 400 and over & - & $195(47.9)$ \\
\hline & Total & $411(100.0)$ & $407(100.0)$ \\
\hline \multirow{4}{*}{$\begin{array}{l}\text { Housing size } \\
\text { (area for } \\
\text { exclusive use) }\end{array}$} & $50 \mathrm{~m}^{2}-60 \mathrm{~m}^{2}$ & $193(37.0)$ & $137(30.6)$ \\
\hline & $85 m^{2}-120 m^{2}$ & $215(41.3)$ & $160(35.8)$ \\
\hline & $135 m^{2}-160 m^{2}$ & $113(21.7)$ & $150(33.6)$ \\
\hline & Total & $90(100.0)$ & $447(100.0)$ \\
\hline \multirow{4}{*}{$\begin{array}{l}\text { Residence } \\
\text { period in their } \\
\text { apartments }\end{array}$} & 2 years or under & $118(24.0)$ & $97(22.6)$ \\
\hline & $3-4$ years & $187(38.1)$ & $112(26.1)$ \\
\hline & 5-6 years or more & $186(37.9)$ & $220(51.3)$ \\
\hline & Total & $491(100.0)$ & $429(100.0)$ \\
\hline
\end{tabular}

\section{RESEARCH RESUlT}

\section{A. Satisfaction with Community Space}

The first survey found that residents were overall satisfied with the provided facilities, which included a children's playground, green spaces, walking/jogging paths, and garbage disposal facilities, etc. In the second survey, respondents were satisfied (with an average score of 3.0 or greater) with all the provided facilities but the community halls. When comparing the two survey results, significant differences were found in satisfaction with the children's playground, outdoor activity places, complex landmarks, green spaces, walking/jogging paths and garbage disposal facilities. The second survey revealed lower satisfaction with the children's playground and the garbage disposal facilities. This is attributable to deterioration in the aforementioned facilities, which thus failed to meet the evolving needs of the residents'. In contrast, green spaces and walking/jogging paths had been further developed and increased over time, thus delivering higher satisfaction in the second survey (Table III).

TABLE III: SATISFACTION WITH COMMUNITY SPACES

\begin{tabular}{|c|c|c|c|c|}
\hline Items & $1^{\text {st }}$-Survey & $2^{\text {nd }}$-Survey & total & $\mathrm{t}$ - value \\
\hline Meeting room & $3.0(0.8)$ & $2.9(0.7)$ & $3.0(0.7)$ & 1.6 (n.s) \\
\hline $\begin{array}{l}\text { Elderly community } \\
\text { center }\end{array}$ & $3.0(0.7)$ & $3.1(0.7)$ & $3.0(0.7)$ & $-1.6(\mathrm{n} . \mathrm{s})$ \\
\hline Daycare center & $3.0(0.8)$ & $3.0(0.6)$ & $3.0(0.7)$ & 0.1 (n.s) \\
\hline Children's playground & $3.4(0.7)$ & $3.1(0.6)$ & $3.2(0.7)$ & $6.3(* * *)$ \\
\hline $\begin{array}{l}\text { Outdoor exercise } \\
\text { facilities }\end{array}$ & $2.7(0.9)$ & $3.0(0.7)$ & $2.9(0.9)$ & $-6.1(* * *)$ \\
\hline Rest facilities & $3.2(0.9)$ & $3.2(0.6)$ & $3.2(0.8)$ & $-0.9(n . s)$ \\
\hline $\begin{array}{l}\text { Apartment's } \\
\text { environmental sculpture }\end{array}$ & $2.9(0.8)$ & $3.2(0.8)$ & $3.1(0.8)$ & $-4.8(* * *)$ \\
\hline Green space & $3.2(0.8)$ & $3.5(0.9)$ & $3.4(0.9)$ & $-4.7(* * *)$ \\
\hline Walking/jogging paths & $3.2(0.9)$ & $3.4(0.8)$ & $3.3(0.9)$ & $-3.8(* * *)$ \\
\hline $\begin{array}{c}\text { Separate garbage } \\
\text { collection facility }\end{array}$ & $3.3(0.8)$ & $3.2(0.8)$ & $3.3(0.9)$ & $3.5(* *)$ \\
\hline
\end{tabular}




\section{B. Use of Community Space}

Except for walking/jogging paths, all items discussed in the survey reported significantly lower usage in the second survey. In particular, senior centers, childcare facilities and outdoor activity areas which were highly utilized in the first survey, were found to be rarely utilized in the second. This may be because apartment complexes have failed to maintain such facilities or because more residents turned to local cultural centers to fulfill these needs.

Although the use of community spaces dramatically dropped, satisfaction was found to have increased in the second survey. This can be construed to mean that residents put greater value on community spaces and give positive evaluation for the fact that they have such facilities and spaces within the apartment complexes regardless of their utilization (Table IV).

TABLE IV: USE OF COMMUNITY SPACES

\begin{tabular}{|c|c|c|c|c|}
\hline Items & $1^{\text {st }}$-Survey & $2^{\text {nd }}$-Survey & total & t- value \\
\hline Meeting room & $3.0(0.9)$ & $1.7(1.0)$ & $2.4(1.1)$ & $19.4(* * *)$ \\
\hline Elderly community cente & r 4.4(0.9) & $1.6(0.9)$ & $3.0(1.7)$ & $43.7(* * *)$ \\
\hline Daycare center & $4.0(1.1)$ & $1.6(1.1)$ & $2.9(1.6)$ & $32.5(* * *)$ \\
\hline Children's playground & $3.2(1.1)$ & $2.2(1.0)$ & $2.7(1.1)$ & $15.3(* * *)$ \\
\hline Outdoor exercise facilitie & $3.9(1.0)$ & 2.1(1.1) & $3.0(1.4)$ & $24.6(* * *)$ \\
\hline Rest facilities & $3.0(0.9)$ & $2.3(1.0)$ & $2.7(1.0)$ & $10.6(* * *)$ \\
\hline $\begin{array}{l}\text { Apartment's } \\
\text { environmental sculpture }\end{array}$ & $3.3(0.8)$ & $2.6(1.1)$ & $3.0(1.0)$ & $9.8(* * *)$ \\
\hline Green space & $2.9(0.8)$ & $3.2(1.1)$ & $3.0(1.0)$ & $-5.4(* * *)$ \\
\hline Walking/jogging paths & $2.9(0.9)$ & $2.8(1.2)$ & $2.9(1.1)$ & $1.4(\mathrm{n} . \mathrm{s})$ \\
\hline $\begin{array}{l}\text { Separate garbage } \\
\text { collection facility }\end{array}$ & $2.3(0.9)$ & $3.6(1.1)$ & $2.9(1.2)$ & $-18.6(* * *)$ \\
\hline
\end{tabular}

\section{Demands for Community Spaces}

In general, strong demands were found for more green spaces, walking/jogging paths, fitness facilities, indoor playgrounds, senior welfare facilities and garbage disposal facilities. This implies that residents desired greater access to exercise facilities and to green spaces to better enrich their lives. Demands for specific family members, such as children and senior citizens, were also prominent. In contrast, decreased demands were found only for guest rooms, business PC rooms, indoor/outdoor house-chore places and shared warehouses. Such functions may be no longer needed or may be housed by other facilities within the complex. Indeed, some of the facilities had already transformed into other functions.

Demands for most items increased in the second survey. This indicates that residents have a greater need for a more diverse range of facilities to improve quality of life. Thus, proactive measures should be taken to accommodate such changing demands (see Table V).
TABLE V: NEEDS OF COMMUNITY SPACES

\begin{tabular}{|c|c|c|c|c|}
\hline Items & $1^{\text {st }}-$ Survey & $2^{\text {nd }}-$ Survey & total & $\begin{array}{l}\text { t- } \\
\text { value } \\
\text { (sig.) }\end{array}$ \\
\hline Apartment's sculpture & $2.5(1.7)$ & $3.2(0.9)$ & $2.9(1.4)$ & $\begin{array}{l}-8.1 \\
(* * *)\end{array}$ \\
\hline Square and minipark & $2.7(1.6)$ & $3.7(0.9)$ & $3.2(1.4)$ & $\begin{array}{l}-11.9 \\
(* * *)\end{array}$ \\
\hline $\begin{array}{l}\text { Waterfront sace (pond, } \\
\text { fountain etc.) }\end{array}$ & $2.8(1.7)$ & $3.6(0.9)$ & $3.2(1.5)$ & $\begin{array}{l}-8.9 \\
(* * *)\end{array}$ \\
\hline $\begin{array}{l}\text { Rest facilities(bench, } \\
\text { pergola) }\end{array}$ & $2.9(1.8)$ & $3.9(0.8)$ & $3.4(1.5)$ & $\begin{array}{l}-11.1 \\
(* * *)\end{array}$ \\
\hline Green space & $3.0(1.8)$ & $4.1(0.9)$ & $3.5(1.5)$ & $\begin{array}{l}-12.8 \\
(* * *)\end{array}$ \\
\hline Walkway & $3.2(1.8)$ & $4.1(0.9)$ & $3.6(1.5)$ & $\begin{array}{l}-10.3 \\
(* * *)\end{array}$ \\
\hline Club lounge(cafeteria) & $2.8(1.2)$ & $3.2(0.9)$ & $3.0(1.1)$ & $\begin{array}{l}-5.7 \\
(* * *)\end{array}$ \\
\hline Guest room & $2.4(1.2)$ & $2.7(1.0)$ & $2.5(1.1)$ & $\begin{array}{l}-4.4 \\
(* * *)\end{array}$ \\
\hline $\begin{array}{l}\text { Business room(home } \\
\text { office facilities) }\end{array}$ & $2.5(1.2)$ & $2.5(1.0)$ & $2.5(1.1)$ & $\begin{array}{l}0.1 \\
\text { (n.s) }\end{array}$ \\
\hline $\begin{array}{l}\text { Multipurpose spaces } \\
\text { (meeting, hobby) }\end{array}$ & $3.2(1.2)$ & $3.3(0.9)$ & $3.2(1.1)$ & $\begin{array}{l}-2.1 \\
(*)\end{array}$ \\
\hline $\begin{array}{l}\text { Area for natural } \\
\text { ecology learning }\end{array}$ & $2.8(1.6)$ & $3.4(1.0)$ & $3.1(1.4)$ & $\begin{array}{l}-6.8 \\
(* * *)\end{array}$ \\
\hline Fitness center & $3.8(1.1)$ & $3.8(0.9)$ & $3.8(1.0)$ & $\begin{array}{l}-0.1 \\
(\mathrm{n} . \mathrm{s})\end{array}$ \\
\hline $\begin{array}{l}\text { Outdoor exercise } \\
\text { space }\end{array}$ & $3.1(1.8)$ & $3.7(0.9)$ & $3.4(1.5)$ & $\begin{array}{l}-7.5 \\
(* * *)\end{array}$ \\
\hline $\begin{array}{l}\text { Outdoor children's } \\
\text { playground }\end{array}$ & $2.8(1.7)$ & $3.9(0.9)$ & $3.3(1.5)$ & $\begin{array}{l}-12.5 \\
(* * *)\end{array}$ \\
\hline $\begin{array}{l}\text { Indoor children's } \\
\text { playground }\end{array}$ & $3.4(1.2)$ & $3.6(1.0)$ & $3.5(1.1)$ & $\begin{array}{l}-1.7 \\
(\mathrm{n} . \mathrm{s})\end{array}$ \\
\hline Afterschool class & $3.2(1.3)$ & $3.4(0.9)$ & $3.3(1.1)$ & $\begin{array}{l}-3.1 \\
(* *)\end{array}$ \\
\hline Youth welfare space & $3.5(1.2)$ & $3.4(0.9)$ & $3.4(1.1)$ & $\begin{array}{l}1.6 \\
\text { (n.s) }\end{array}$ \\
\hline Elderly welfare space & $3.6(1.2)$ & $3.7(0.9)$ & $3.6(1.1)$ & $\begin{array}{l}-1.6 \\
\text { (n.s) }\end{array}$ \\
\hline $\begin{array}{l}\text { Indoor housework } \\
\text { space }\end{array}$ & $2.6(1.2)$ & $3.2(1.1)$ & $2.9(1.2)$ & $\begin{array}{l}-8.4 \\
(* * *)\end{array}$ \\
\hline $\begin{array}{l}\text { Outdoor housework } \\
\text { space (large laundry } \\
\text { etc.) }\end{array}$ & $2.3(1.5)$ & $3.1(1.0)$ & $2.6(1.3)$ & $\begin{array}{l}-10.2 \\
(* * *)\end{array}$ \\
\hline $\begin{array}{l}\text { Warehouse (large } \\
\text { stuff, seasonal stuff } \\
\text { etc.) }\end{array}$ & $2.6(1.3)$ & $3.0(1.1)$ & $2.8(1.2)$ & $\begin{array}{l}-5.1 \\
(* * *)\end{array}$ \\
\hline $\begin{array}{l}\text { Separate garbage } \\
\text { collection space }\end{array}$ & $3.6(1.3)$ & $4.0(0.9)$ & $3.7(1.1)$ & $\begin{array}{l}-5.3 \\
(* * *)\end{array}$ \\
\hline $\begin{array}{l}\text { Storage place for } \\
\text { bicycle and stroller }\end{array}$ & $3.1(1.8)$ & $3.7(1.0)$ & $3.4(1.5)$ & $\begin{array}{l}-7.5 \\
(* * *)\end{array}$ \\
\hline
\end{tabular}

$* * * p<.000, * * p<.01, * p<.05$, n.s means no significant

\section{CONCLUSION}

This study is designed to develop greater understanding of changes in the use of and demands for apartment community 
spaces. It thus intends to serve as a basis for future development of sustainable apartment complexes and suggests the following:

1) It is necessary to design community spaces that encourage resident participation and that accommodate evolving demands. Existing policy guidelines that focus only on the size of community facilities in accordance with the number of households should be modified so that apartment complexes must more flexibly develop community spaces to encompass resident needs and desires.

2) Measures should be developed to extend the scope of the community and to establish a network of unit communities, beyond a single siloed community for each apartment complex. As the survey results demonstrate, wider and greater demands are arising for community spaces. Given the limited land use within apartment complexes, this study recommends the development of a single community center shared amongst 3-4 neighboring apartment complexes.

3) It is also important to secure a specialized workforce which designs, operates and manages community spaces for healthy and sustainable apartment communities.

This study is based on the Korean apartment development and housing culture, but it should be noted that each country may have different understandings of community design for residents. This study is significance in that it proposed a direction to design community spaces for sustainable apartment communities by analyzing the constant and changing characteristics of community spaces.

\section{REFERENCES}

[1] S. H. Cho and T. K. Lee, "A study on building sustainable communities in high-rise and high-density apartments," Building and Environment, vol. 46, no. 7, pp. 1428-1435, July 2011.

[2] Y. K. Noh and Y. S. Hwang, "A space usage and user Evaluation of community facility in high rise mixed-use apartment," Journal of the Korean Housing Association, vol. 18, no. 2, pp. 39-47, April 2007.

[3] A. H. Khalid, "Towards a sustainable neighborhood: The role of open space," Archnet-IJAR, International Journal of Architectural Research, vol. 2, no. 2, pp.162-177, 2008.

[4] R. Y. Lee and N. S. Shin, "A study of the influence of the physical structure in the apartment complex on sense of community - Focusing on apartment complex in Gwangju metropolitan City," Architecture Institute of Korea, vol. 25, no. 3, pp. 235-246, March 2009.

[5] D. C. W. Ho, K. W. Chau. A. K. C. Cheung, Y. Yau, S. K. Wong, H. F. Leung, S. S. Y. Lau, and W. S. Wong, "A survey of the health and safety conditions of apartment buildings in hong kong," Building and Environment, vol. 43, no. 5, pp. 764-775, 2008.

[6] S. J. Seo and H. S. Baik, "A field study on the spatial changing uses of service facilities in multi-family housing," Architecture Institute of Korea, vol. 20, no. 11, pp. 219-230, November 2004.

[7] Y. S. Shin and T. G. Yon, "An analysis of residents' needs for residents' common service facilities in apartment housings across family life cycle stages," Architecture Institute of Korea, vol. 22, no. 6, pp. 57-64, June 2006.

[8] S. H. Cho and H. G. Kang, "A study on the residents' attitude for the shared community space of apartment," Journal of the Korean Housing Association, vol. 9, no. 3, pp. 47-57, November 1998.

[9] O. J. Kwon, I. S. Kwak, K. H. Rhee, and J. S. Choi, "A study on the activity programs at community center for citizens' welfare toward new millennium," Journal of the Korean Home Economic Association, vol. 39, no. 8, pp. 19-35, 2001.

[10] D. M. Chavis and A. Wandersman, "Sense of community in urban environment : A catalyst for participation and community development," Journal of community Psychology, vol. 18, pp. 55-79, 1990.

[11] G. Moser, "Quality of life and sustainability: Toward person-environment congruity," Journal of Environmental Psychology, vol. 29, pp. 351-357, 2009

[12] V. Maliene and N. Malys, "High-quality housing- A key issue in delivering sustainable communities," Building and Environment, vol. 44, pp. 426-430, 2009.

[13] C. W. F. Yu and J. T. Kim, "Holistic Health Considerations to Prevent Sick Buildings for a Sustainable Caring Society," Indoor and Built Environment, vol. 22, no. 1, pp. 5-6, 2013.

[14] R. Bond, "Toward sustainable living in an ageing society," Revolutions in Urban Space Planning, pp. 35-41, 2009.

[15] P. M. Bluyssen, "Towards new methods and ways to create healthy and comfortable buildings," Building and Environment, vol. 45, pp. 808-818, 2010.

[16] S. H. Cho, T. K, Lee, and J. T. Kim, "Residents' satisfaction of indoor environmental quality in their old apartment homes," Indoor and Built Environment, vol. 20, no. 1, pp. 16-25, 2011.

[17] I. Y. Choi, S. H. Cho, and J. T. Kim, "Energy consumption characteristics of high-rise apartment buildings according to building shape and mixed-use development," Energy and Buildings, vol. 16, pp. 123-131, March 2012.

[18] N. N, Kang, T. K. Lee, and J. T. Kim, "Characteristics of the Quality of Korean High-Rise Apartments Using the Health Performance Indicator," Indoor and Built Environment, vol. 22, no. 1, pp. 157-167, February 2013.

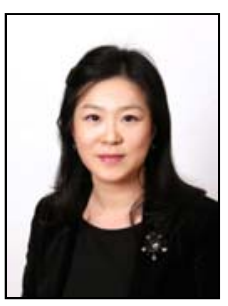

Tae Kyung Lee was born in 1979. She received the MSc and PhD at Pusan National University of South Korea, majored on Housing and Interior Design and joined the Digital Interactive Design at Inje University and Elderly Research Institute at Pusan National University as main researcher. She is up-and-coming professor and as an assistant professor of Housing and Interior Design at Pusan National University since 2012. And she has joined the project of Center for Sustainable Healthy Buildings as core researcher.

Prof. Lee's research interests include indoor environmental quality, healthy housing design, environment and behavior research (EBR), multi-family housing (design and evaluation), and community design \& regeneration.

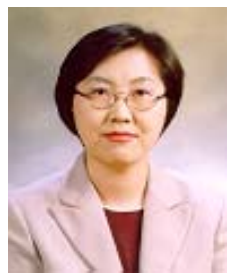

Hye Gyoung Kang was born in 1966. She received the MSc at Kyung Sung University and the PhD at Pusan National University in South Korea, majored on home management.

She worked at Design Institute of Inje University, Elderly Research Institute of Pusan National University, and Domestic Science Institute of Dong A University as main researcher. She is now assistant professor of Department of Nutrition \& Human Care at Kyung Sung University in South Korea.

Dr. Kang's research interests include environmental behavior and psychology, community design, and home management.

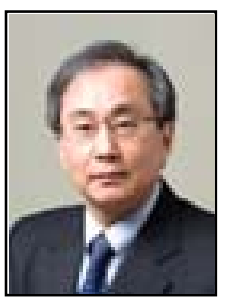

Jeong Tai Kim is a Kyung Hee Distinguished Fellow at Kyung Hee University and is a fellow of the Korea Academy of Science and Technology (KAST). In September of 2008, He founded the center for sustainable healthy buildings $(\mathrm{CSHeB})$ with the award of engineering research center (ERC) from Korea Government. As the director of the $\mathrm{CSHeB}$, he has tried to establish an outstanding R\&D center with global competitiveness by providing on-site research facilities, formulating synergistic interconnection with interdisciplinary researchers, and promoting collaboration and cooperation with various industries, government departments, and international universities. He also plays a key role in promoting sustainable healthy building technologies academically by hosting international symposiums, seminars, and workshops. He acted as the president of the Acoustical Society of Korea (2005), the Korea Institute of Ecological Architecture and Environment (2007 - 2008), and currently acts as the President of the Korea Society of Lighting and Visual Environment and the vice-president of the International Society of the Built Environment 